\title{
Pengaruh Kompetensi Sumber Daya Manusia dan Locus of Control terhadap Kualitas Laporan Keuangan LPD
}

\author{
Ni Wayan Sudiarti ${ }^{1}$ \\ Fakultas Ekonomi dan Bisnis \\ Universitas Udayana, Indonesia \\ Email: niwayansudiarti26@gmail.com
}

\author{
Gede Juliarsa² \\ Fakultas Ekonomi dan Bisnis \\ Universitas Udayana, Indonesia
}

\begin{abstract}
ABSTRAK
Tujuan dari penelitian ini, yaitu untuk mngetahui bagaimana pengaruh dari kompetensi sumber daya manusia dan locus of control terhadap kualitas laporan keuangan Lembaga Perkreditan Desa (LPD) di Kabupaten Klungkung. Populasi dalam penelitian ini adalah seluruh LPD Kabupaten Klungkung. Penentuan sampel dalam penelitian ini menggunakan rumus slovin dengan purposive sampling, yaitu memperoleh sebanyak 46 sampel. Metode pengumpulan data yang digunakan adalah metode survei dengan menyebarkan kuesioner dan dokumentasi. Jumlah kuesioner yang kembali sebanyak 126 kuesioner. Metode analisis data yang dalam penelitian ini adalah analisis regresi linear berganda dengan SPSS. Berdasarkan hasil penelitian, kompetensi sumber daya manusia dan locus of control berpengaruh positif dan signifikan terhadap kualitas laporan keuangan. Hasil penelitianini diharapkan dapat memberikan tambahan wawasan ilmu pengetahun bagi pihak-pihak yang berperan dalam menyusun laporan keuangan sehingga mampu mencapai keberhasilan dalam menjalankan tugas-tugasnya.
\end{abstract}

Kata Kunci: Kualitas Laporan Keuangan; Kompetensi Sumber Daya Manusia; Locus Of Control.

\section{The Effect of Human Resource Competencies and Locus of Control on The Quality of LPD Financial Statements}

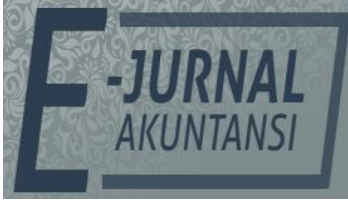

E-JA

e-Jurnal Akuntansi e-ISSN 2302-8556

Vol. 30 No. 7

Denpasar, Juli 2020

Hal.1725-1737

Artikel Masuk: 2 Februari 2020

Tanggal Diterima: 17 Juni 2020

\begin{abstract}
The purpose of this study to determine the effect of human resource competencies and locus of control on the quality of Institute of Countryside Credit (LPD) financial reports. The population in this study were all LPD of Klungkung Regency. The sample technique in this study using the Slovin formula with purposive sampling, as many as 46 samples. Data collection method used is a survey method by distributing questionnaires and documentation. The number of returned questionnaires was 126 questionnaires. The data analysis technique used is doubled linear regression analysis with SPSS. Based on research results, competence of human resources and locus of control have a positive and significant effect on the quality of financial statements. The results of this study are expected to provide additional insights into knowledge for those who play a role in preparing financial reports so as to achieve success in carrying out their duties.
\end{abstract}

ABSTRACT

Keywords: Financial Report Quality; Human Resource Competencies; Locus Of Control.

The Article is Available in: https://ojs.unud.ac.id/index.php/Akuntansi/index 


\section{PENDAHULUAN}

Berdasarkan Pernyataan Standar Akuntansi Keuangan (PSAK) No. 1 Tahun 2017 Tentang Penyajian Laporan Keuangan, "laporan keuangan adalah suatu penyajian terstruktur dari posisi keuangan dan kinerja keuangan suatu entitas. Tujuan laporan keuangan adalah untuk memberikan informasi mengenai posisi keuangan, kinerja keuangan, dan arus kas entitas yang bermanfaat bagi sebagian besar pengguna laporan keuangan dalam pembuatan keputusan ekonomi." Laporan keuangan merupakan suatu informasi yang menggambarkan kondisi keuangan suatu organisasi, di mana nantinya dijadikan sebagai sumber informasi dalam menilai kinerja suatu organisasi (Anggayana \& Wirajaya, 2019). Laporan keuangan dalam suatu entitas sangat memiliki pengaruh pada informasi manajemen, yang mana pada setiap periode akuntansi laporan keuangan harus disampaikan guna mengetahui bagaimana perkembangan entitas baik dari segi pemasukan maupun pengeluaran, serta posisi keuangan yang lainnya di mana saling behubungan dengan informasi keuangan perusahaan (Rahmayuni, 2017). Laporan keuangan adalah pernyataan dalam komponen laporan keuangan entitas pelapor yang merupakan pertanggungjawaban manajemen keuangan selama suatu periode ( Afiah \& Rahmatika, 2014).

Berdasarkan pendapat dari Kordlouie et al., (2014) laporan keuangan bertujuan menjelaskan kinerja dari suatu entitas demi membantu stakeholders mengambil keputusan ekonomi. Menurut penelitian Mcdaniel et al., (2002) kualitas dari laporan keuangan dikatakan baik apabila laporan keuangan dapat menciptakan informasi bermanfaat untuk pemakai dalam membuat keputusan ekonomi. Informasi akan bermanfaat apabila informasi dapat mendukung pengambilan keputusan dan andal (Kusuma et al., 2014). Informasi yang diberikan dalam laporan keuangan mencerminkan kinerja mereka dalam periode akuntansi tertentu dan mengungkapkan nilai perusahaan (Ferdinand \& Santosa, 2018). Tentunya dalam setiap lembaga keuangan menginginkan laporan keuangan yang dihasilkan oleh bendahara keuangannya berupa laporan keuangan yang berkualitas karena demi kemajuan lembaga keuangan itu sendiri.

Kualitas laporan keuangan memiliki peran yang sangat penting dalam membantu pengambilan keputusan terkait operasional entitas atau organisasi, salah satu entitas yang sangat penting memiliki laporan keuangan yang berkualitas adalah lembaga keuangan lokal yang berasal dari Bali, yakni Lembaga Perkreditan Desa (LPD). Saat ini Indonesia memiliki lembaga keuangan lokal yang tersebar di berbagai wilayah, salah satunya Lembaga Perkreditan Desa (LPD). LPD adalah suatu badan perekonomian desa di mana berfungsi sebagai suatu wadah penyimpanan dana, penyaluran kredit, serta sumber pendanaan dalam rangka suatu pembangunan desa yang ada di Bali (Paramitha \& Dharmadiaksa, 2019). LPD menyediakan dana untuk operasional serta dalam rangka mencapai tujuan memberikan manfaat kepada warga desa adat. Manajemen LPD sama halnya dengan pemerintahan Desa Adat, yakni atas dasar prinsip kekeluargaan dan pelayanan jasa keuangan yang dilaksanakan berdasarkan prinsip saling percaya (Paramitha \& Dharmadiaksa, 2019).

Laporan keuangan yang berkualitas memiliki kegunaan untuk pihak-pihak yang bersangkutan antara lain: pihak pemilik desa adat, pihak pengurus, pihak 
nasabah (nasabah peminjam dan penyimpan) dan pihak Pembina (Pariani et al., 2016). Dengan adanya laporan keuangan berkualitas tersebut, maka LPD juga akan mampu menumbuhkan kepercayaan masyarakat sehingga kemungkinan dapat meningkatkan jumlah nasabah suatu LPD. Dalam menanamkan rasa percaya masyarakat terhadap LPD dilakukan dengan menunjukkan kinerja keuangan yang tertuang dalam laporan keuangan LPD tersebut, di mana kinerja keuangan adalah suatu analisis bertujuan untuk melihat perkembangan entitas dalam melaksanakan operasionalnya sesuai dengan aturan-aturan pelaksanaan keuangan yang telah ditentukan (Pariani et al., 2016).

LPD memiliki suatu keunikan dapat dilihat dari karakteristiknya, yaitu kerangka peraturannya didasarkan pada peraturan pemerintah Bali, dikelola sendiri dan diatur sendiri yang terintegrasi dengan aturan desa adat, menerima modal awal yang kecil, tetapi kemudian menjadi lembaga yang dibiayai sendiri, dan mekanisme kontrolnya didasarkan pada nilai-nilai budaya dan agama (Suadi et al., 2019). Meskipun dalam perkembangannya LPD menjalankan fungsi dan tujuannya dapat dikatakan berhasil, akan tetapi tidak seluruh LPD mengalami keberhasilan tersebut, salah satunya beberapa LPD yang tersebar di Kabupaten Klungkung. Terdapat LPD yang sangat pesat kemajuannya, namun sebaliknya ada juga LPD yang masih berkembang. Sangat diperlukannya suatu penelitian dalam menghadapi kondisi seperti ini sehingga dapat terjawab hal-hal apa yang dapat mempengaruhi suatu keberhasilan sebuah lembaga LPD. Dalam melihat sebuah LPD maju atau tidak, salah satunya terlepas bagaimana kualitas laporan keuangannya. Berdasarkan Lembaga Pemberdayaan Lembaga Perkreditan Desa (LPLPD) Kabupaten Klungkung tahun 2018, terdapat 117 LPD yang tersebar di Kabupaten Klungkung, yang mana 80 LPD berkondisi sehat, 22 LPD kondisi cukup sehat, 6 LPD dalam kondisi kurang sehat, dan 9 LPD tidak beroperasi. Beberapa kondisi LPD yang kurang sehat dan tidak beroperasi tersebut menjadi suatu fenomena yang membuat peneliti tertarik untuk melakukan penelitian di LPD Kabupaten Klungkung.

Kualitas laporan keuangan menghasilkan informasi yang bermanfaat bagi pengguna, informasi yang memenuhi karakteristik kualitatif informasi atau karakteristik kualitas informasi keuangan (Tambingon et al., 2018). Untuk memenuhi kualitas informasi akuntansi, maka informasi tersebut harus dapat dipahami oleh para pengambil keputusan (Yadnyana et al., 2017). Dalam menyusun sebuah laporan keuangan berkualitas, terdapat empat karakteristik kualitatif laporan keuangan yang harus diperhatikan, yaitu dapat dipahami, relevan, andal, dan dapat dibandingkan. Demi tersusunnya laporan keuangan dengan empat karakteristik kualitatif tersebut, maka diperlukannya peran Sumber Daya Manusia (SDM) yang berkompeten dan didukung oleh aspek yang terdapat pada setiap individu yang disebut dengan locus of control. Berdasarkan Peraturan Gubernur Bali Nomor 44 Tahun 2017 Tentang Petunjuk Pelaksanaan Peraturan Daerah Provinsi Bali Nomor 3 Tahun 2017 Tentang Lembaga Pekreditan Desa Bagian Kedua, Organisasi dan Pengambilan Keputusan Strategis Pasal 2 menyebutkan bahwa, "(1) Organisasi LPD terdiri dari Pengawas dan Pengurus LPD, (2) Pengurus LPD sebagaimana dimaksud pada ayat (1) berasal dari krama Desa Pakraman dan krama Desa Pakraman ditetapkan melalui Paruman bersama Prajuru Desa Pakraman dan Desa Pakraman". Dalam 
merekrut pengurus LPD, hanya sesuai dengan hasil musyawarah Desa Adat, hal ini merupakan salah satu kelemahan LPD dalam pengelolaan sumber daya manusia (Paramitha \& Dharmadiaksa, 2019). Hal ini kemungkinan dapat menyebabkan suatu manajemen LPD tidak berkembang dengan baik, bahkan dapat mengalami kebangkrutan (Paramitha \& Dharmadiaksa, 2019). Meningkatnya lembaga keuangan, baik bank maupun non-bank, membuat persaingan untuk lembaga keuangan termasuk LPD semakin ketat (Budiasni et al., 2018). Dengan demikian, LPD harus memiliki kemampuan daya saing dengan sektor perbankan yang telah berkembang dengan pesat.

Dalam penelitian Paramitha \& Dharmadiaksa (2019), dijelaskan bahwa kompetensi karyawan memiliki pengaruh positif terhadap kualitas laporan keuangan. Adapun hasil temuan Zuliarti (2012) yang menjelaskan bahwa sumber daya manusia terdapat pengaruh terhadap nilai informasi laporan keuangan. Kemudian, dalam hasil temuan Aswandi (2018) menjelaskan bahwa kompetensi sumber daya manusia memiliki pengaruh negatif pada kualitas laporan keuangan.

Salah satu unsur penting kinerja individu yang terdapat di dalam diri seseorang, yakni locus of control (Rotter, 1966). Suatu persepsi seseorang pada sebuah pencapaian ketika bertindak di segala aktivitas dalam hidupnya disebut locus of control (Wibowo, 2010). Locus of control adalah kendali atas suatu pekerjaan yang dilakukan individu dan kepercayaan atas keberhasilan diri (Yuliani \& Juliarsa, 2016). Menurut Kreitner \& Kinicki, (2001) terdapat dua unsur locus of control, yakni internal dan eksternal. Internal locus of control adalah jika seseorang percaya bahwa suatu kejadian selalu berada dalam kendalinya, selalu berperan, dan bertanggungjawab dalam tindakan pengambilan keputusan. Eksternal locus of control adalah jika seseorang yang percaya bahwa suatu kejadian dalam hidupnya berada di luar kendalinya. Pada suatu entitas peran dari locus of control sangat penting karena dalam diri masing-masing individu terdapat pengendalian diri yang berbeda-beda (Raditya \& Wirajaya, 2018).

Pada penelitian Karuniawan et al., (2017) menyatakan bahwa locus of control berpengaruh positif pada kualitas laporan keuangan. Selain itu, hasil penelitian yang ditemukan Radityastuti et al., (2017) bahwa terdapat pengaruh positif antara locus of control dengan kinerja analis kredit. Berbeda dengan hasil penelitian dari Sudiartini (2018) bahwa terdapat pengaruh negative antara locus of control eksternal dengan kinerja individu. Locus of control juga dinyatakan tidak memiliki pengaruh pada kinerja auditor oleh penelitian Mindarti (2015).

Kondisi suatu manajer yang mana tidak mengutamakan kepentingan individu, tetapi lebih mengutamakan tujuan dan kepentingan suatu organisasi, hal ini digambarkan dalam teori stewardship (Davis et al., 1997). Menurut penelitian Eddleston \& Kellermanns (2007), teori stewardship menunjukkan hubungan yang saling percaya, lingkungan yang berorientasi keterlibatan dan memberdayakan struktur organisasi akan meningkatkan perilaku pro-organisasi dan kinerja perusahaan. Asumsi dari teori ini adalah manajemen sebagai pihak yang berintegritas, memiliki kejujuran dan mampu bertindak dengan penuh tanggung jawab dalam melaksanakan tindakannya yang ditunjukkan untuk memenuhi kebutuhan baik stakeholders maupun shareholders. 
Sumber Daya Manusia (SDM) adalah salah satu elemen yang penting dalam organisasi. SDM adalah pilar utama suatu organisasi dibandingkan dengan unsur-unsur lain, seperti teknologi ataupun uang karena manusia sendiri yang dapat mengendalikan unsur-unsur tersebut (Anggriawan \& Yudianto, 2018). Kompetensi adalah faktor kunci untuk menentukan seseorang dalam menghasilkan kinerja yang sangat baik (Hidayah \& Zarkasyi, 2017). Analisis kompetensi sebagian besar dikhususkan untuk pengembangan karir dan tingkat kompetensi diperlukan untuk menentukan efektivitas tingkat kinerja yang diharapkan (Wardhani, 2017). Kompetensi SDM adalah kemampuan individu di dalam suatu organisasi/kelembagaan, atau sistem demi melaksanakan tugastugas atau kewenangannya dalam mencapai suatu keberhasilan secara efisien dan efektif (Ihsanti, 2014). Dalam hal ini kompetensi SDM menghasilkan laporan keuangan. Dalam memaksimalkan kinerja demi suatu kualitas laporan keuangan, maka SDM harus mempunyai pengetahuan yang baik tentang tugasnya, misalnya pengetahuan pada standar akuntansi yang menjadi suatu basis dalam penyusunan laporan keuangan.

Hubungan kompetensi SDM di bidang akuntansi dengan kualitas laporan keuangan mengacu pada hasil penelitian yang ditemukan Paramitha \& Dharmadiaksa (2019), Agung \& Gayatri (2018), Karuniawan et al., (2017), Hanifa et al., (2016), Pramudiarta \& Juliarto (2015), dan Wiranata et al., (2015) yang membuktikan bahwa terdapat pengaruh positif antara kompetensi sumber daya manusia dengan kualitas laporan keuangan. Kemudian, dalam penelitian Suliyantini \& Kusmuriyanto (2017) menemukan kompetensi sumber daya manusia memiliki pengaruh positif dengan kualitas laporan keuangan. Sesuai dengan hal itu, penelitian yang dilakukan Ardiyanto et al., (2016) menjelaskan sumber daya manusia memiliki pengaruh positif pada keandalan laporan keuangan.

$\mathrm{H}_{1}$ : Kompetensi sumber daya manusia berpengaruh positif terhadap kualitas laporan keuangan.

Locus of control adalah suatu konsep yang menjelaskkan kepercayaan setiap individu tentang kejadian-kejadian yang dialami dalam hidupnya. Hal tersebut termasuk keyakinan terhadap suatu pencapaian ketika bertindak di segala aktivitas dalam hidupnya yang berasal dari suatu kendali dari dalam dirinya ataupun kendali di luar dirinya. Bertindak dalam segala kegiatan di dalam hidupnya yang dikaitkan dengan faktor eksternal locus of control, diantaranya nasib, keberuntungan, kekuasaan atasan dan lingkungan kerja serta faktor internal locus of control yang di dalamnya mencakup potensi kerja dan suatu pelaksanaan kerja yang berkaitan dengan kesuksesan dan ketidaksuksesan individu yang terkait (Wibowo, 2010).

Penelitian ini mengacu pada penelitian yang ditemukan oleh Karuniawan et al., (2017), yakni bahwa locus of control memiliki pengaruh positif signifikan pada kualitas laporan keuangan. Selain itu, dalam penelitian yang ditemukan oleh Radityastuti et al., (2017), yaitu locus of control berpengaruh positif pada kinerja analis kredit serta dalam penelitian Wiriani et al., (2013) menyatakan bahwa pengaruh utama level locus of control terhadap kinerja signifikan, artinya kinerja kelompok karyawan level locus of control internal lebih tinggi dibandingkan kinerja kelompok level locus of control external. Pengelola LPD, 
yaitu pengurus LPD itu sendiri sangat penting memiliki locus of control karena locus of control memiliki peran terhadap motivasi kinerja pegawai. Perbedaan locus of control yang dimiliki masing-masing individu dapat menggambarkan motivasi dan kinerja yang berbeda.

$\mathrm{H}_{2}$ : Locus of Control berpengaruh positif terhadap kualitas laporan keuangan LPD.

\section{METODE PENELITIAN}

Dalam penelitian yang dilakukan, peneliti menggunakan pendekatan kuantittif bersifat asosiatif. Pengambilan data-data melalui instrumen penelitian. Analisis data bersifat kuantitatif, yakni untuk menguji hipotesis yang telah ditentukan (Sugiyono, 2017:16). Penelitian ini berbentuk asosiatif dengan tujuan, yakni untuk mengetahui bagaimana kaitan antara dua variabel atau lebih (Sugiyono, 2017:20).

Penelitian ini dilakukan di LPD Kabupaten Klungkung. Adanya suatu alasan LPD Kabupaten Klungkung sebagai tempat dilakukannya penelitian, yaitu karena adanya kondisi dari beberapa LPD kurang sehat, dan juga ada dalam kondisi tidak beroperasi. Dengan adanya kondisi seperti ini, maka perlu diketahui dan diteliti hal tersebut, sehingga dapat diketahui hal-hal apa yang dapat mempengaruhi perkembangan suatu LPD salah satunya, yaitu dengan meneliti kualitas laporan keuangan yang telah dihasilkan.

Adapun dalam penelitian ini terdapat variabel dependen $(Y)$, yaitu laporan keuangan LPD. Kemudian, variabel independen $(X)$ dalam penelitian ini, yaitu kompetensi sumber daya manusia $\left(\mathrm{X}_{1}\right)$ dan locus of control $\left(\mathrm{X}_{2}\right)$. Kompetensi sumber daya manusia adalah kemampuan individu di dalam suatu organisasi atau suatu sistem demi melaksanakan tugas-tugas atau kewenangannya dalam menggapai suatu keberhasilan dengan efisien dan efektif (Ihsanti, 2014). Variabel kompetensi sumber daya manusia diukur melalui indikator, yaitu pengetahuan, keterampilan, dan sikap. Suatu persepsi seseorang pada sebuah keberhasilan ataupun kegagalan dalam bertindak di segala aktivitas dalam hidupnya disebut locus of control. Adapun faktor eksternal locus of control mencakup nasib, keberuntungan, kekuasaan atasan dan lingkungan kerja dan adapun faktor internal locus of control mencakup potensi dan tindakan kerja yang berkaitan dengan kesuksesan dan kegagalan kerja individu (Wibowo, 2010).

Locus of control terbagi menjadi dua unsur, yakni internal locus of control dan eksternal locus of control. Adapun indikator dari eksternal locus of control, yakni suatu kegagalan yang terjadi karena adanya ketidakmujuran, per encanaan jauh ke depan dan pekerjaan yang sia-sia dilakukan, suatu peristiwa yang terjadi dalam hidup tergantung ketentuan yang diberlakukan oleh atasan, dan suatu keberhasilan individu disebabkan oleh faktor nasib. Adapun indikator dari internal locus of control, yaitu sesuatu yang digapai oleh individu berasal dari kerja keras diri sendiri, menjadi pimpinan adalah hasil potensi diri, keberhasilan individu karena usaha sendiri, suatu capaian yang dihasilkan individu bukan dari faktor keberuntungan, suatu kejadian dalam kehidupan seseorang tergantung dari tindakannya, dan suatu kegagalan yang terjadi akibat perbuatan sendiri. Laporan keuangan adalah catatan informasi keuangan suatu perusahaan pada suatu periode akuntansi yang dapat digunakan untuk menggambarkan 
kinerja perusahaan tersebut (Ikatan Akuntansi Indonesia, 2015). Indikator kualitas laporan keuangan yang dimaksud, yaitu relevan, andal, dapat dibandingkan, dan dapat dipahami.

Populasi dalam penelitian ini adalah LPD se-Kabupaten Klungkung berdasarkan data dari Lembaga Pemberdayaan Lembaga Perkreditan Rakyat (LPLPD) Kabupaten Klungkung 2019 yang terdiri dari 117 LPD. Dalam penelitian ini peneliti mempersempit populasi, yaitu jumlah seluruh LPD Kabupaten Klungkung dengan menghitung ukuran sampel melalui rumus slovin (Sugiyono, 2017:87). Teknik sampling yang digunakan dalam penelitian ini dengan menggunakan non probability sampling dengan purposive sampling. Sampel yang didapat berjumlah 46 LPD dengan responden dalam penelitian ini, yaitu seluruh pegawai LPD yang berperan dalam menyusun laporan keuangan sebanyak 138 orang.

Dalam penelitian ini jenis data yang digunakan adalah data kualitatif dan data kuantitatif. Metode pengumpulan data dalam penelitian ini adalah metode survei dengan pemberian kuesioner berupa pernyataan mengenai pengaruh kompetensi sumber daya manusia dan locus of control terhadap kualitas laporan keuangan LPD. Selain itu, peneliti melakukan dokumentasi data laporan keuangan LPD.

Instrumen yang digunakan dianalisis validitas dan reliabilitasnya, kemudian dilakukan uji statistik deskriptif, uji asumsi klasik, dan uji regresi linear berganda. Hasil analisis regresi linear berganda, berikutnya akan dilakukan uji koefisien determinasi R2, uji kelayakan model (uji F) dan uji hipotesis (uji $t$ ). Berikut ini persamaan regresi yang digunakan.

$Y=\alpha+\beta_{1} X_{1}+\beta_{2} X_{2}+\mu$

\section{HASIL DAN PEMBAHASAN}

Berdasarkan hasil uji validitas, maka dapat dinyatakan bahwa semua indikator pernyataan di dalam kuesioner dengan variabel kualitas laporan keuangan $(Y)$, kompetensi sumber daya manusia $\left(\mathrm{X}_{1}\right)$, dan locus of control $\left(\mathrm{X}_{2}\right)$ memiliki nilai pearson correlation yang lebih besar dari 0,30 sehingga seluruh indikator tersebut telah memenuhi syarat validitas data. Berdasarkan hasil uji reliabilitas Nilai Cronbach's Alpha yang dihasilkan oleh variabel kualitas laporan keuangan (Y) sebesar 0,923, kompetensi SDM $\left(X_{1}\right)$ sebesar 0,919 dan locus of control $\left(X_{2}\right)$ sebesar 0,916. Nilai Cronbach's Alpha yang dihasilkan lebih besar dari 0,70 sehingga dapat dinyatakan bahwa kuisioner yang digunakan telah memenuhi syarat reliabel.

Dalam penelitian ini, analisis statistik deskriptif digunakan dengan tujuan untuk melakukan analisa data melalui cara menggambarkan data yang telah dikumpulkan sebagaimana adanya, tanpa memiliki maksud untuk menarik kesimpulan yang berlaku umum atau generalisasi (Sugiyono, 2017:232). Tabel 1. menunjukkan bahwa jumlah pengamatan $(\mathrm{N})$ penelitian ini berjumlah 126.

Nilai minimum yang dimiliki variabel kualitas laporan keuangan adalah sebesar 20 dan nilai maksimumnya sebesar 45 serta nilai rata-ratanya sebesar 38,21. Standar deviasi pada variabel kualitas laporan keuangan sebesar 4,689. Pada variabel kompetensi SDM menghasilkan nilai minimum sebesar 11 dan nilai maksimum sebesar 40 dengan nilai rata-rata sebesar 34,11. Standar deviasi pada variabel kompetensi SDM adalah sebesar 4,935. Variabel locus of control 
memiliki nilai minimum sebesar 10 dan nilai maksimum sebesar 25 dengan nilai rata-rata sebesar 20,81. Standar deviasi yang dimiliki variabel locus of control adalah sebesar 2,932.

\section{Tabel 1. Hasil Statistik Deskriptif}

\begin{tabular}{clccccc}
\hline No. & \multicolumn{1}{c}{ Variabel } & N & Min & Max & Mean & $\begin{array}{c}\text { Std. } \\
\text { Deviation }\end{array}$ \\
\hline 1 & Kualitas Laporan & 126 & 20 & 45 & 38,21 & 4,689 \\
& Keuangan $(\mathrm{Y})$ & & & & & \\
2 & KompetensiSDM $\left(\mathrm{X}_{1}\right)$ & 126 & 11 & 40 & 34,11 & 4,935 \\
3 & Locus Of Control $\left(\mathrm{X}_{2}\right)$ & 126 & 10 & 25 & 20,81 & 2,932 \\
\hline
\end{tabular}

Sumber: Data Penelitian, 2020

Berdasarkan hasil uji normalitas Asymp. Sig. (2-tailed) sebesar 0,200 lebih besar dari level of significant sebesar 0,05 sehingga dapat dinyatakan bahwa data berdistribusi normal. Berdasarkan hasil uji multikolinearitas dapat ditunjukkan bahwa nilai Tolerance masing-masing variabel bebas memiliki nilai lebih dari 0,10 dan nilai VIF kurang dari 10, sehingga dapat dinyatakan bahwa tidak terdapat gejala multikolinearitas antarvariabel bebas. Pada hasil uji heteroskedastisitas menjelaskan bahwa semua variabel memiliki nilai signifikansi yang lebih besar dari $a=0,05$. Hal ini dapat dikatakan bahwa model regresi ini bebas dari gejala heteroskedastisitas. Dapat diamati hasil dari analisis regresi linear berganda pada Tabel 2.

Tabel 2. Hasil Analisis Regresi Linear Berganda

\begin{tabular}{|c|c|c|c|c|c|}
\hline \multirow[t]{2}{*}{ Model } & \multicolumn{2}{|c|}{$\begin{array}{l}\text { Unstandardized } \\
\text { Coefficients }\end{array}$} & \multirow{2}{*}{$\begin{array}{c}\text { Standardized } \\
\text { Coefficients } \\
\text { Beta }\end{array}$} & \multirow[b]{2}{*}{$\mathrm{T}$} & \multirow[b]{2}{*}{ Sig. } \\
\hline & $\mathrm{B}$ & $\begin{array}{l}\text { Std. } \\
\text { Error }\end{array}$ & & & \\
\hline 1 (Constant) & 7,008 & 1,274 & & 5,500 & 0,000 \\
\hline $\begin{array}{l}\text { KompetensiSDM } \\
\left(X_{1}\right)\end{array}$ & 0,299 & 0,066 & 0,314 & 4,551 & 0,000 \\
\hline $\begin{array}{l}\text { Locus OfControl } \\
\left(\mathrm{X}_{2}\right)\end{array}$ & 1,010 & 0,110 & 0,631 & 9,140 & 0,000 \\
\hline
\end{tabular}

Sumber: Data Penelitian, 2020 berikut:

Berdasarkan Tabel 2, persamaan regresi yang dapat disusun adalah sebagai

$$
\mathrm{Y}=7.008+0.299 \mathrm{X} 1+1.010 \mathrm{X} 2+\mu
$$

Berdasarkan Tabel 2, nilai konstanta benilai positif sebesar 7,008 maka dapat diartikan apabila tidak terdapat pengaruh dari variabel lain atau variabel bebas, maka nilai konstan dari variabel kualitas laporan keuangan (Y) adalah sebesar 7,008. Nilai koefisien variabel kompetensi $\operatorname{SDM}\left(X_{1}\right)$ bernilai positif sebesar 0,299 maka artinya apabila nilai kompetensi SDM $\left(X_{1}\right)$ naik satu satuan maka kualitas laporan keuangan (Y) akan naik sebesar 0,299, sehingga dapat dikatakan bahwa kompetensi SDM $\left(\mathrm{X}_{1}\right)$ berpengaruh positif terhadap kualitas laporan keuangan $(\mathrm{Y})$. Nilai koefisien variabel locus of control $\left(\mathrm{X}_{2}\right)$ bernilai positif sebesar 1,010 maka artinya apabila nilai locus of control $\left(\mathrm{X}_{2}\right)$ naik satu satuan maka kualitas laporan keuangan $(Y)$ akan naik sebesar 1,010, sehingga dapat dikatakan bahwa locus of control $\left(\mathrm{X}_{2}\right)$ berpengaruh positif terhadap kualitas laporan keuangan (Y). 
Sesuai dengan hasil olahan SPSS, menjelaskan bahwa nilai Adjusted $R$ Square, yaitu sebesar 0,830. Hal ini berarti bahwa sebesar $83 \%$ variasi kualitas laporan keuangan $(Y)$ dapat dijelaskan oleh variabel kompetensi SDM $\left(\mathrm{X}_{1}\right)$ dan locus of control $\left(\mathrm{X}_{2}\right)$, sedangkan sisanya dijelaskan oleh variabel lain yang tidak dimasukkan ke dalam model atau penelitian. Diperoleh nilai F hitung sebesar 306,270, nilai $\mathrm{F}$ hitung ini lebih besar dari nilai $\mathrm{F}$ table sebesar 3,07 dan nilai signifikansi F sebesar 0,000 nilai ini lebih kecil dari 0,05 sehingga dapat dinyatakan bahwa terdapat pengaruh signifikan yaitu kompetensi SDM $\left(X_{1}\right)$ dan locus of control $\left(\mathrm{X}_{2}\right)$ terhadap varaibel terikat, yaitu kualitas laporan keuangan $(\mathrm{Y})$ secara simultan. Setelah diuji secara parsial dengan menggunakan uji $\mathrm{t}$, diperoleh nilai $\mathrm{T}$ hitung sebesar 4,551, nilai $\mathrm{T}$ hitung ini lebih besar dari nilai $\mathrm{T}$ tabel sebesar 1,998. Nilai signifikansinya sebesar 0,000 nilai ini lebih kecil dari 0,05 sehingga dapat dinyatakan bahwa terdapat pengaruh positif dan signifikan antara kompetensi SDM $\left(\mathrm{X}_{1}\right)$ terdahap kualitas laporan keuangan $(\mathrm{Y})$.

Suatu kompetensi SDM sangat dibutuhkan untuk menghasilkan susunan laporan keuangan yang berkualitas baik. SDM yang mempunyai kemampuan dan keahlian akuntansi, akan mempermudah pegawai dalam menyusun laporan keuangan. Selain itu, SDM yang berkompeten dapat meminimalisasi terjadinya kesalahan yang mungkin dapat berdampak pada hasil dari laporan keuangan yang dibuat. Penelitian ini sama halnya dengan penelitian yang dihasilkan oleh Agung \& Gayatri (2018), dan Kiranayanti \& Erawati (2016) yang membuktikan bahwa kompetensi SDM memiliki pengaruh positif dan signifikan pada kualitas laporan keuangan. Temuan Hertati (2015) pun menjelaskan kompetensi SDM memiliki pengaruh positif dan signifikan pada kualitas pelaporan keuangan.

Berdasarkan uji secara parsial dengan menggunakan uji t, diperoleh nilai $\mathrm{T}$ hitung sebesar 9,140 nilai T hitung ini lebih besar dari nilai T tabel sebesar 1,998. Nilai signifikansinya sebesar 0,000 nilai ini lebih kecil dari 0,05 sehingga dapat dinyatakan bahwa terdapat pengaruh positif dan signifikan antara locus of control $\left(\mathrm{X}_{2}\right)$ terdahap kualitas laporan keuangan $(\mathrm{Y})$.

Pengurus LPD itu sendiri sangat penting mempunyai locus of control karena locus of control memiliki peran dalam memotivasi kinerja pegawai. Perbedaan locus of control yang dimiliki setiap individu/seseorang dapat menggambarkan motivasi dan kinerja yang berbeda pula. Penelitian ini searah dengan penelitian yang ditemukan Karuniawan et al., (2017) menyatakan bahwa locus of control berpengaruh positif signifikan terhadap kualitas laporan keuangan. Selain itu, dalam penelitian yang dihasilkan oleh Radityastuti et al., (2017), yaitu locus of control berpengaruh positif pada kinerja analis kredit serta dalam penelitian Wiriani et al., (2013) menyatakan bahwa pengaruh utama level locus of control terhadap kinerja signifikan, artinya kinerja kelompok karyawan level locus of control internal lebih tinggi dibandingkan kinerja kelompok level locus of control external.

\section{SIMPULAN}

Adanya pengaruh positif antara kompetensi Sumber Daya Manusia (SDM) dengan kualitas laporan keuangan LPD Kabupaten Klungkung. Hal ini berarti bahwa semakin baik kompetensi yang dimiliki SDM, maka semakin baik pula kualitas laporan keuangan yang dihasilkan. Adanya pengaruh positif antara 
locus of control dengan kualitas laporan keuangan LPD Kabupaten Klungkung. Hal ini berarti bahwa semakin karyawan memiliki suatu keyakinan dengan tingkat yang tinggi terhadap pentingnya kualitas laporan keuangan yang dimiliki LPD Kabupaten Klungkung, maka semakin baik kualitas laporan keuangan yang dihasilkan.

Sesuai dengan simpulan yang telah didapatkan, maka peneliti dapat memberikan saran, yaitu kepada peneliti berikutnya, sebaiknya menggunakan variabel selain kompetensi SDM dan locus of control karena diduga juga akan memiliki pengaruh pada kualitas laporan keuangan dan sudah cukup banyak penelitian lain yang menggunakan variabel ini, serta diharapkan untuk melakukan sesi tanya jawab secara langsung terhadap pegawai LPD yang terkait dalam variabel yang akan diteliti, demi memperkuat hasil penelitian. Kemudian, diharapkan juga untuk membenahi kuesioner pada variabel locus of control agar dapat menghasilkan temuan yang lebih maksimal dari penelitian yang akan dilakukan terhadap variabel locus of control.

\section{REFERENSI}

Afiah, N. N., and Rahmatika, D. N. (2014). Factors Influencing The Quality of Financial Reporting and Its Implications on Good Government Governance (Research on Local Government Indonesia). International Journal of Business, Economics and Law, 5(1), 111-121.

Agung, T. M., dan Gayatri. (2018). Analisis Faktor-faktor yang Mempengaruhi Kualitas Laporan Keuangan Pemerintah Daerah Kabupaten Karangasem. EJurnal Akuntansi Universitas Udayana, 23(2), 1253-1276.

Anggayana, I. P. N., dan Wirajaya, I. G. A. (2019) Pengaruh Prinsip-prinsip Good Governance dan Budaya Organisasi terhadap Kinerja Keuangan Lembaga Perkreditan Desa Kota Denpasar. E-Jurnal Akuntansi Universitas Udayana, 298(1), 325-341..

Anggriawan, F. T., and Yudianto, I. (2018). Factors Affecting Information Quality of Local Government Financial Statement. Journal of Accounting Auditing and Business, 1(1), 30-42.

Ardiyanto, H., Hermanto, dan Surasni, N. K. (2016). The effect of information technology, adherence to accounting rules, and human resources on the reliability of financial statements in Central Lombok District Government. The Indonesian Accounting Review, 6(2), 195-206.

Budiasni, N., Ayuni, S., and Sanjaya, W. S. (2018). Sustainability Performance of Village Credit Institutions (LPD) in Buleleng Regency. International Journal of Social Science and Business, 2(4), 210-216.

Eddleston, K., \& Kellermanns, F. (2007). Destructive and Productive Family Relationships: A Stewardship Theory Perspective. Journal of Business Venturing, 22, 545-565. https://doi.org/10.1016/j.jbusvent.2006.06.004

Ferdinand, R., and Santosa, S. (2018). Factors that Influence Fraudulent Financial Statements in Retail Companies - Indonesia. JAAF (Journal of Applied Accounting and Finance), 2(2), 99-109.

Hanifa, L. (2016). Pengaruh Kompetensi Pengelola Keuangan dan Sistem Akuntansi Keuangan Daerah terhadap Kualitas Laporan Keuangan. Jurnal

Progres Ekonomi Pembangunan, 1(2), 65-80. 
https://doi.org/10.33772/jpeb.v1i2.1803

Hertati, L. (2015). Competence of Human Resources, The Benefits of Information Technology on Value of Financial Reporting in Indonesia. Research Journal of Finance and Accounting, 6(8).

Hidayah, N., and Zarkasyi, W. (2017). The Effect of Human Resources Management Competency and the Role of Culture on Accrual Accounting Implementation Effectiveness and the Impact on Quality of Accounting Information. European Research Studies Journal, XX(4), 183-199.

Ihsanti, E. (2014). Pengaruh Kompetensi Sumber Daya Manusia dan Penerapan Sistem Akuntansi Keuangan Daerah terhadap Kualitas Laporan Keuangan Daerah. Artikel Ilmiah UNP.

Ikatan Akuntansi Indonesia. (2015). Exposure Draft: Kerangka Konseptual Pelaporan keuangan. Jakarta: Dewan Standar Akuntansi Keuangan.

Ikatan Akuntansi Indonesia. (2017). Pernyataan Standar Akuntansi Keuangan (PSAK) No.1 Penyajian Laporan Keuangan. Jakarta: Dewan Standar Akuntansi Keuangan.

Karuniawan, W. M., Sujana, E., dan Yuniarta, G. A. (2017). Pengaruh Kompetensi Sumber Daya Manusia, Penerapan Teknologi Informasi, dan Locus Of Control Terhadap Kualitas Laporan Keuangan Pada Lembaga Pengkreditan Desa (LPD) di Kabupaten Buleleng Barat. E-Journal Akuntansi Universitas Pendidikan Ganesha, 8(2).

Kiranayanti, I., \& Erawati, N. (2016). Pengaruh Sumber Daya Manusia, Sistem Pengendalian Intern, Pemahaman Basis Akrual Terhadap Kualitas Laporan Keuangan Daerah. E-Jurnal Akuntansi, 16(2), 1290-1318.

Kordlouie, H., Mohammadi, F., Naghshineh, N., \& Tozandejani, M. (2014). Role of Accounting Conservatism on the Quality of Financial Statements. 9(1), 129-139. https://doi.org/10.5539/ijbm.v9n1p129

Kreitner, R., \& Kinicki, A. (2001). Organizational Behavior. Fifth Ed. Irwin McGraw Hill:Boston.

Kusuma, A., Herawati, dan Yunilma. (2014). Pengaruh Kapasitas Sumber Daya Manusia dan Pemanfaatan Teknologi Informasi, terhadap Nilai Informasi Pelaporan Keuangan Pemerintah Daerah (Studi pada Pemerintah Daerah Kabupaten Dharmasraya) Tahun 2014. E-Jurnal Akuntansi Universitas Bung Hatta, 4(1).

McDaniel, L., Martin, R. D., \& Maines, L. A. (2002). Evaluating financial reporting quality: The effects of financial expertise vs. financial literacy. In Accounting Review. https://doi.org/10.2308/accr.2002.77.s1.139

Mindarti, C. S. (2015). Pengaruh Karakteristik Individu terhadap Kinerja Auditor. Jurnal Ekonomi dan Bisnis, 17(3). https://doi.org/10.24914/jeb.v18i3.286

Paramitha, A. A. I. P., \& Dharmadiaksa, I. B. (2019). Pengaruh Kompetensi Karyawan dan Teknologi Informasi pada Kualitas Laporan Keuangan LPD Dengan Pendidikan Sebagai Pemoderasi. E-Jurnal Akuntansi Universitas Udayana, 26(1), https://doi.org/https://doi.org/10.24843/EJA.2019.v26.i01.p25

Pariani, N. M. A., Yudiaatmaja, F., dan Suwendra, I. W. (2016). Analisis Tingkat Kesehatan LPD Ditinjau dengan Metode Capital, Assets, Earning, Liquidity (CAEL). E-Journal Bisma Universitas Pendidikan Ganesha Jurusan Manajemen. 
Pemerintah Provinsi Bali. Peraturan Gubernur Bali Nomor 44 Tahun 2017 Tentang Petunjuk Pelaksanaan Peraturan Daerah Provinsi Bali Nomor 3 Tahun 2017 Tentang Lembaga Perkreditan Desa. (2017). Bali.

Pramudiarta, R., dan Juliarto, A. (2015). The Influence of Human Resource Competence, Technology Utilization, and Internal Control System Against Value of Financial Reporting Information Local Government Accounting Entity (Empirical Study of SKPD Officials in Batang and Kendal Regencies), Diponegoro Journal of Accounting, 4(3), 1-14. https://doi.org/http://ejournal-s1.undip.ac.id/index.php/accounting

Raditya, P. A., dan Wirajaya, I. G., A. (2018). Pengaruh Partisipasi Anggaran dan Penekanan Anggaran pada Senjangan Anggaran dengan Locus Of Control sebagai Variabel Pemoderasi. E-Jurnal Akuntansi Universitas Udayana, 22(2), 1584-1599.

Radityastuti, A. A. A. R., Astika, I. B. P., dan Wirakusuma, M. G. (2017). Pengaruh Locus of Control pada Kinerja Analis Kredit dengan Motivasi dan Lingkungan Kerja sebagai Pemoderasi. E-Jurnal Ekonomi dan Bisnis Universitas Udayana, 6(6), 2503-2528.

Rahmayuni, S. (2017). Peranan Laporan Keuangan dalam Menunjang Peningkatan Pendapatan Pada UKM. JSHP ( Jurnal Sosial Humaniora Dan Pendidikan), 1(1), 93. https://doi.org/10.32487/jshp.v1i1.239

Rotter, J.B. (1966). Generalized Expectancies for Internal Versus External Control of Reinforcement. Pshycologycal Monographs. Vol. 80, pp. 1-28.

Suadi, Wati, R. I., and Mitsuhiro, N. (2019). Inovation in Financing Coastal Village Development through Community-Owned Microfinance Institution: A Case Study of Village Credit Institution (LPD) Kedonganan Bali. Scientific Journal of Fisheries and Marine, 11(2), 1-10.

Sudiartini, Ni Luh Yuli. (2018). Pengaruh Locus of Control dan Budaya Organisasi Berbasis Tri Hita Karana pada Kinerja Badan Pengawas. E-Jurnal Akuntansi Universitas Udayana, 22(1), 381-407.

Sugiyono. (2017). Metode Penelitian Kuantitatif, Kualitatif, dan RED. Bandung: Alfabeta. https://doi.org/10.1017/CBO9781107415324.004

Suliyantini, L., dan Kusmuriyanto. (2017). The Effect of Human Resources Competency and Accrual Based Government Accounting Standard the Implementation of Internal Control System as a. Accounting Analysis Journal, 6(1), 19-26. https://doi.org/10.15294/AAJ.V612.15408

Tambingon, H. N., Yadiati, W. and Kewo, C. L. (2018). Determinant Factors Influencing the Quality of Financial Reporting Local Government in Indonesia. International Journal of Economics and Financial Issues, 8(2), 262-268.

Wardhani, N. K. (2017). Influence of Competence, Transformational Leadership, Social Capital, and Perfomance on Employee Careers. International Journal of Human Capital Management, 1(2), 81-94.

Wibowo, Nurhida Rahmalia. (2010). Hubungan Antara Locus Of Control Internal dengan Selft Efficacy dengan Kepuasan Kerja Karyawan Departemen Spinning PT. Daya Manunggal. Skripsi (diterbitkan). Program Studi Psikologi, Universitas Sebelas Maret Surakarta.

Wiranata, A. A., Hamdi, M., dan Minovia, A. F. (2015). Pengaruh Kompetensi Sumber Daya Manusia Dan Pemanfaatan Teknologi Terhadap Kualitas 
Laporan Keuangan (Studi Empiris UMKM di Kota Padang). Jurnal Akuntansi, 7(1).

Wiriani, W., Piatrini, P. S., Ardana, K., dan Juliarsa, G. (2013). Efek Moderasi Locus of Control pada Hubungan Pelatihan dan Kinerja pada Bank Perkreditan Rakyat di Kabupaten Badung. Jurnal Ilmiah Akuntansi dan Bisnis, 8(2), 99-105.

Yadnyana, I. K., Mertha, M., dan Arka, M. S. (2017). Analysis Of Effectiveness Of Internal Monitoring And Control Institution Of LPD In Bali Province, Indonesia. International Journal of Economics, Commerce and Management, 5(6), 661-673.

Yuliani, G. M. D. O., dan Juliarsa, G. (2016). Tekanan Anggaran Waktu Memoderasi Locus of Control Internal pada Perilaku Underreporting of Audit Time. E-Jurnal Akuntansi Universitas Udayana, 15(3), 1856-1885.

Zuliarti. (2012). Pengaruh Kapasitas Sumber Daya Manusia, Pemanfaatan Teknologi Informasi, dan Pengendalian Intern Akuntansi Terhadap Nilai Informasi Pelaporan Keuangan Pemerintah Daerah: Studi pada Pemerintah Kabupaten Kudus. Jurnal Akuntansi Fakultas Ekonomi dan Bisnis Universitas Muria Kudus. 